\title{
Rapid Toxicity Testing Based on Mitochondrial Respiratory Activity
}

\author{
M. E. Haubenstricker, ${ }^{1}$ S. E. Holodnick, ${ }^{2}$ K. H. Mancy, ${ }^{2}$ and M. J. Brabec ${ }^{3}$ \\ 1 United States Environmental Protection Agency, Motor Vehicle Emissions \\ Laboratory, Ann Arbor, Michigan 48105; 'University of Michigan, School of \\ Public Health, Ann Arbor, Michigan 48109, and ${ }^{3}$ Eastern Michigan University, \\ Chemistry Department, Ypsilanti, Michigan 48197, USA
}

The need exists for rapid and inexpensive methods to determine the health effects of environmental contaminants on biological systems. Whole organism toxicity assays have been based on measuring induced toxic effects in numerous systems such as tissue cultures (Ekwall 1983), sperm cells (Dinnel et al. 1982), and bacteria (Dorward and Barisas 1984, Karube et al. 1982). However, these tests have inherent disadvantages of requiring special facilities, and assessments may take days to complete. Bacterial assays are inexpensive and rapid (Maugh 1979), but are not always sensitive to toxicants which are lethal to higher species such as fish (Dutka and Kwan 1982). One of the current research approaches for assessing cytotoxicity is to monitor the respiratory activity of the mitochondrion, a sensitive, nonspecific subcellular target site (Blondin et al. 1987, Khan and Culkomp 1982, Masini et al. 1983, Ogata et al. 1983, Pisani et al. 1986). This organelle is common to most eukaryotic cells, and is involved in a number of vital cellular processes. Detected changes in mitochondrial function after the addition of a test chemical could be correlated to toxic effects.

Mitochondrial respiration can be characterized by three indices: state 3 and state 4 respiratory rates, and the respiratory control ratio (RCR). State 4 , the idle or resting state, results when coupled mitochondria respire in a medium containing inorganic phosphate and a Kreb's cycle substrate (i.e. succinate) in the absence of a phosphate acceptor such as adenosine diphosphate (ADP). In the presence of ADP the respiration rate increases to a maximum (state 3), accompanied by phosphorylation of $\mathrm{ADP}$ to adenosine triphosphate (ATP). The state 4 rate resumes with limiting ADP levels (Lehninger 1976). The ratio of state 3 to state 4, or RCR, indicates how tightly the oxidative phosphorylation process is coupled (Chance and Williams 1956). The RCR may range from 3 to 7 , but approaches 1 when the mitochondria are damaged or aged (i.e. complete uncoupling).

The synthesis of ATP by mitochondria is influenced by a number of compounds, most of which are either uncouplers or inhibitors (Figure 1). Uncoupling agents prevent ATP synthesis by promoting the dissipation of energy gained through electron transfer; the state 4 rate approaches that of state 3 . Inhibitors of oxidative phosphorylation prevent the ATP-forming mechanism from utilizing the high energy compounds generated from electron transfer. Thus, ATP synthesis is inhibited without increasing the rate of respiration; the state 3 rate approaches a rate similar to state 4 . Inhibitors of electron transfer block the utilization of oxygen and

Send reprint requests to M.E. Haubenstricker at the above address. 


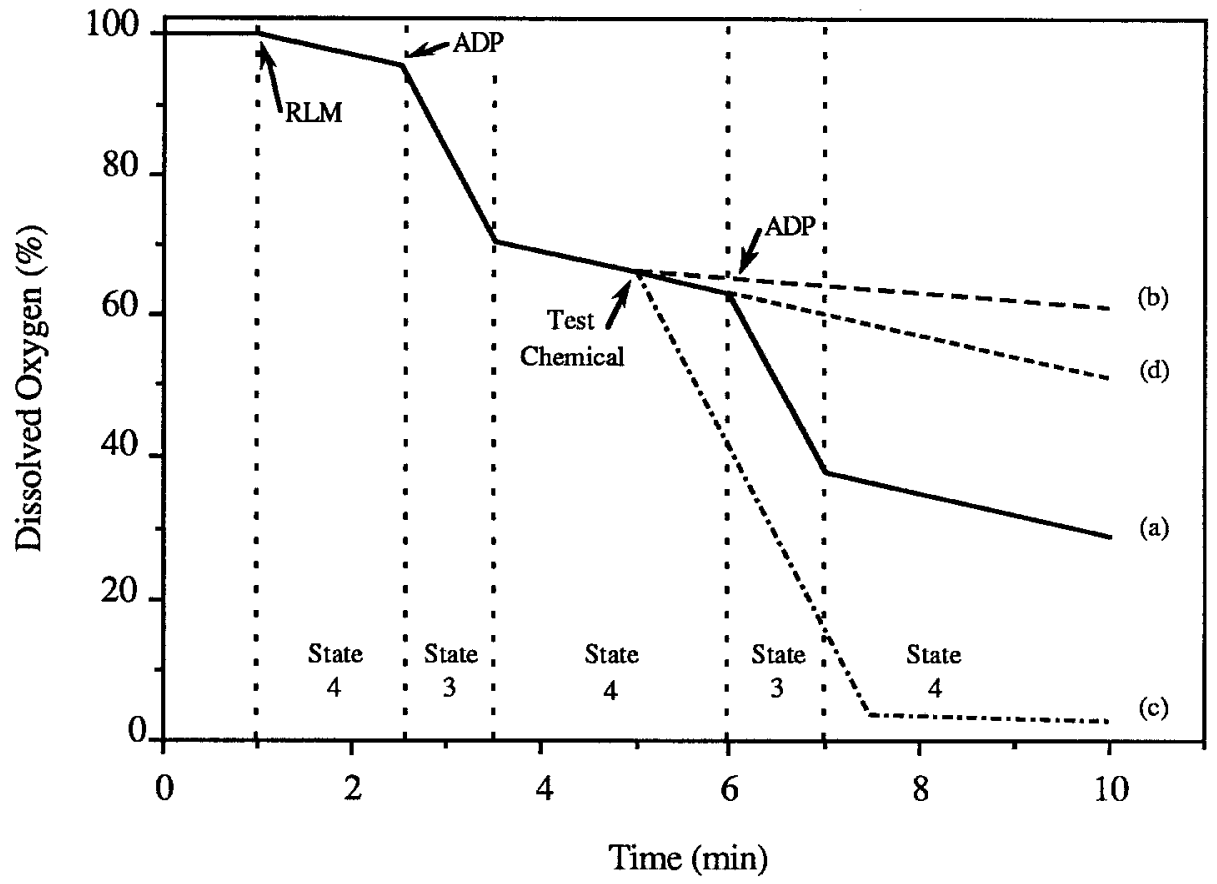

Figure 1. Idealized effects of chemical agents on mitochondrial respiration: (a) no effect detected, (b) inhibition of electron transfer, (c) uncoupling of oxidative phosphorylation, and (d) inhibition of oxidative phosphorylation.

therefore cause cessation of all states of respiration (Tzagoloff 1982).

\section{MATERIALS AND METHODS}

The biological oxygen monitoring system (Yellow Springs Instruments, model \#53) was calibrated with deionized water having dissolved oxygen (DO) concentrations ranging from $0-100 \%$ air saturation, as determined by Winkler titrations (American Public Health Association 1975).

Mitochondria from the livers of two month old male Charles Rivers white rats (strain SD) were isolated and prepared according to Kronenberg and Brabec (1982). To minimize variance, the mitochondria from the livers of four rats were

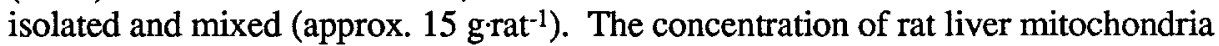
(RLM) protein was determined by the Biuret colorimetric protein assay (Jacobs et al. 1956), using bovine serum albumin as the standard. The assay medium consisted of $0.15 \mathrm{M}$ sucrose, $5 \mathrm{mM} \mathrm{MgCl} 2,10 \mathrm{mM} \mathrm{KH}_{2} \mathrm{PO}_{4}, 20 \mathrm{mM} \mathrm{KCl}, 20 \mathrm{mM}$ tris(hydroxymethyl)aminomethane, and $4 \mathrm{mM}$ succinic acid, final $\mathrm{pH} 7.4$.

For each toxicity assay, $25 \mu \mathrm{L}$ RLM suspension $\left(78.5 \pm 1.1 \mathrm{mg}\right.$ protein $\left.\cdot \mathrm{mL}^{-1}\right)$ was injected into the assay chamber containing $2.5 \mathrm{~mL}$ air saturated assay media at $30.0^{\circ} \mathrm{C}$. After a steady state respiration rate was achieved, $10.0 \mu \mathrm{L}$ ADP $(41 \mathrm{mM}$; Sigma, grade VI) was injected to induce state 3 . After state 4 resumed, an aliquot of test solution was injected. Once state 4 was again established, $10.0 \mu \mathrm{L}$ ADP was 
injected to again produce state 3 . Based on 72 assays, average initial state 3 and state 4 values were $68.7 \pm 0.1$ and $15.3 \pm 0.1 \mathrm{ng} \mathrm{O}_{2} \cdot \mathrm{mg}$ protein ${ }^{-1} \cdot \mathrm{min}$, respectively, and the average RCR value was $4.54 \pm 0.54$. Percent change from control values for state 3 , state 4, and RCR were calculated from data obtained before and after the addition of the test solution.

Chemicals for assessment of the toxicity sensor were chosen based on water quality criteria as set forth in the United States Environmental Protection Agency (USEPA) list of priority pollutants (1979). Tested compounds included: isophorone, naphthalene, chlordane, $\mathrm{n}$-nitrosodimethylamine, potassium cyanide, chloroform, diethyl phthalate, potassium dichromate, mercuric chloride, cupric chloride, and 2,4-dinitrophenol (2,4-DNP). Malathion was also included in this study as a representative of organophosphate pesticides. Solutions of the test chemicals were prepared in deionized water, stored at $0-4^{\circ} \mathrm{C}$, and brought to room temperature before use.

\section{RESULTS AND DISCUSSION}

The concentration of DO in air saturated RLM assay media was found to be 7.05 $\mathrm{mg} \mathrm{O}_{2} \cdot \mathrm{L}^{-1}$. The electrode response to DO in deionized water was linear through the range $0-7.45 \mathrm{mg} \mathrm{O}_{2} \cdot \mathrm{L}^{-1}$, with a sensitivity of $36.9 \mathrm{nAmpere} \cdot \mathrm{L} \cdot \mathrm{mg}{ }^{-1}$. For all assays: $\mathrm{T}=30.0 \pm 0.2^{\circ} \mathrm{C}, \mathrm{P}=750 \pm 5$ torr.

Malathion, isophorone, naphthalene, chlordane, and n-nitrosodimethylamine induced no observable effects on RLM respiratory activity over the tested concentration ranges $(195 \mathrm{nM}-81.5 \mu \mathrm{M}, 1.98 \mathrm{nM}-825 \mu \mathrm{M}, 97.8 \mathrm{nM}-40.9 \mu \mathrm{M}, 53.4$ pM - 22.6 nM, and $3.96 \mu \mathrm{M}-1.66 \mathrm{mM}$, respectively).

Malathion is a phosphorodithioate and acts as an anticholinesterase upon activation. Activation is effected by conversion of the thionates to their corresponding oxygen analogs (Casarett and Doull 1980). The enzyme systems required to catalyze the conversion are found in the cellular microsomes which were not included in the assay media. The time required for each toxicity assay would not favor significant derivative formation even with microsomal activation.

Isophorone is known to affect kidneys and cornea, naphthalene is biotransformed into retinotoxic products, chlordane affects the central nervous system, and nnitrosodimethylamine ultimately causes fatty acid build-ups and necrosis of the liver (Casarett and Doull 1980). Therefore, although these compounds are also known to be toxic to whole biological systems, there was little indication that they would affect mitochondrial activity.

Cyanide ion and diethyl phthalate produced a progressive inhibition in all respiration indices over the tested concentration ranges $(10.6-210 \mu \mathrm{M}$ and $14.7-615$ $\mu \mathrm{M}$, respectively). This effect is indicative of electron transfer inhibition. Due to system design and solubility limitations, concentrations of diethyl phthalalte necessary to affect a $50 \%$ change from initial rates $\left(\mathrm{EC}_{50}\right)$ were not achieved.

Chloroform and dichromate ion (2.05 - $856 \mu \mathrm{M}$ and $2.00-836 \mu \mathrm{M}$, respectively) produced progressive state 3 inhibition but did not affect state 4 rates. This effect isunderstood as an inhibition of oxidative phosphorylation. Again, due to system design and solubility limitations, $\mathrm{EC}_{50}$ values could not be determined. 


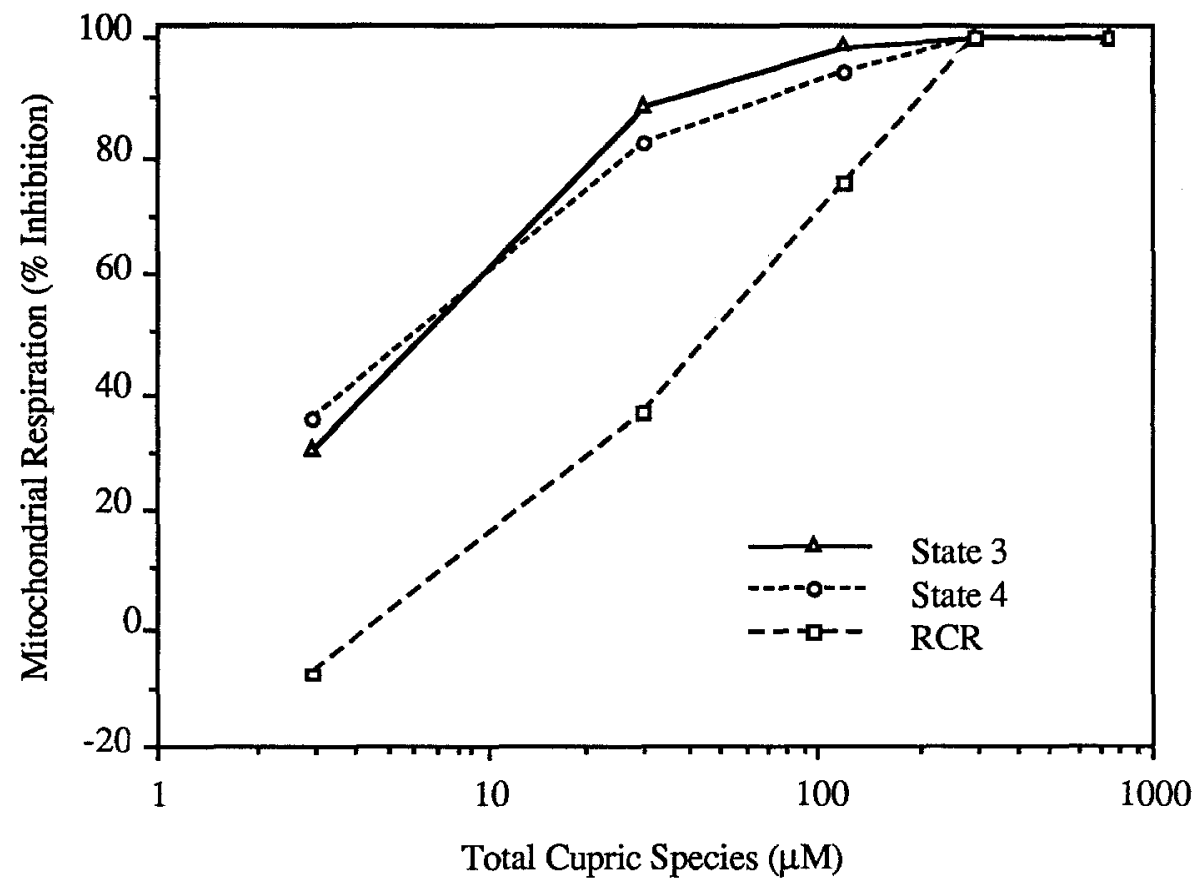

Figure 2. Effect of cupric chloride on rat liver mitochondria respiration.

Mercuric ion, 2,4-DNP, and cupric ion (1.92 - $75.7 \mu \mathrm{M}, 954 \mathrm{nM}-399 \mu \mathrm{M}$, and $2.97-737 \mu \mathrm{M}$, respectively) induced large initial stimulations of state 4 rates at low concentrations $(\leq 5 \mu \mathrm{M})$, which subsided in about $0.5 \mathrm{~min}$. At higher concentrations $(<150 \mu \mathrm{M})$ the three respiration indices for the mercuric and cupric ion tests approached complete inhibition. A typical dose-response curve for cupric ion is presented in Figure 2. These effects are similar to those reported for $\mathrm{Zn}^{2+}$ (Kleiner 1974). An initial uncoupling of oxidative phosphorylation in conjunction with electron transfer inhibition could account for the variance in the generated doseresponse relationships for these test compounds. From the results of the most concentrated sample of 2,4-DNP assayed, it was unclear whether or not the three respiration parameters were approaching complete inhibition.

This test was designed to be a rapid, non-specific means to assess acute toxicity. However, numerous procedures can be added to provide further information. For instance, the toxic effect from dichromate ion was assumed to be an inhibition of oxidative phosphorylation. This conclusion was clarified when no stimulation in respiration was observed after adding the uncoupler 2,4-DNP. The initial uncoupling effect observed with mercuric and cupric ions could be due to the ions short circuiting the respiratory chain, causing a redox cycle with oxygen. This effect could be determined by addition of an electron transfer inhibitor. When cyanide ionwas added to a cupric ion toxicity test, the respiration was inhibited, which indicated that the original effect was due to uncoupling and not redox cycling.

$\mathrm{EC}_{50}$ values for the three $\mathrm{RLM}$ respiration indicies are presented in Table 1. $L D_{50}$ values for other systems are also included in the table for comparison. Compounds tested that indicated no effect on mitochondrial respiration are not included in the 
Table 1. $\mathrm{EC}_{50}$ values of isolated rat liver mitochondria ( $\left.\mathrm{RLM}\right)$ for selected test chemicals and $\mathrm{LD}_{50}$ values for other systems.

\begin{tabular}{|c|c|c|c|c|}
\hline \multirow[b]{2}{*}{ Chemical } & \multicolumn{3}{|c|}{$\mathrm{EC}_{50}(\mu \mathrm{M})$, Mitochondria $^{\alpha}$} & \multirow[b]{2}{*}{$\begin{array}{c}\text { Oral Route } \\
\text { LD }_{50}(\mathrm{mg} / \mathrm{kg}), \text { Specie }^{\beta}\end{array}$} \\
\hline & $\begin{array}{c}\text { State } 4 \\
\text { (stimulation) }\end{array}$ & $\begin{array}{c}\text { State } 3 \\
\text { (inhibition) }\end{array}$ & $\begin{array}{c}\mathrm{RCR} \\
\text { (decrease) }\end{array}$ & \\
\hline$\overline{\text { Potassium cyanide }}$ & * & 25 & 80 & $\begin{array}{l}8.5 \text {, mouse; } 10 \text {, rat; } \\
2.857 \text {, human }\end{array}$ \\
\hline Mercuric chloride & 3 & 4 & 3.5 & $\begin{array}{l}10, \text { mouse; } 1.37 \text {, rat; } \\
29 \text {, human }\end{array}$ \\
\hline Cupric chloride & 3 & 6 & 7 & 190 , mouse; 140 , rat \\
\hline 2,4-Dinitrophenol & 4 & 30 & 15 & $\begin{array}{l}45, \text { mouse; } 30 \text {, rat; } \\
4.3 \text {, human }\end{array}$ \\
\hline
\end{tabular}

a Determined concentrations to effect $50 \%$ changes from control values

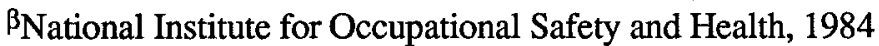

* $\mathrm{EC}_{50}$ not observed over the concentration range tested

table. There are numerous reasons for poor correlations between the $\mathrm{EC}_{50}$ values from this test and reported $\mathrm{LD}_{50}$ values. Some compounds known to affect whole systems have no specific effect on the mitochondrial system. Some compounds must first be enzymatically transformed (i.e., the P450 system) into a toxic form before an effect is produced. Structures of an intact organism could also be capable of shielding the mitochondria from compounds that are toxic to these organelles, but are less toxic to components of the whole organism (i.e. the cell membrane).

The mitochondrion is the center of respiration in almost all eukaryotic cells. Numerous studies have used the mitochondrion to assess enzymatic respiratory pathways, which has led to the development of the current bioassay system. This system can serve as a rapid, inexpensive technique to assess the toxicity of certain environmental contaminants on mitochondrial respiration.

Acknowledgments. This work was supported by the United States Environmental Protection Agency.

\section{REFERENCES}

American Public Health Association (1975) Standard Methods for the Examination of Water and Wastewater. 14th ed Washington, pp 443-447

Blondin GA, Knobeloch LM, Read HW, Harkin JM (1987) Mammalian mitochondria as in vitro monitors of water quality. Bull Environ Contam Toxicol $38: 467-474$

Casarett LJ, Doull J (1980) Toxicology, the Basic Science of Poisons, 2nd ed Macmillan, New York

Dinnel PA, Stober QJ, Crumley SC, Nakatani RE (1982) Development of a sperm cell toxicity test for marine waters. In: Pearson JG, Foster RB, Bishop WE (eds) Aquatic Toxicology and Hazard Assessment, ASTM STP 766. American Society for Testing and Materials, Philadelphia pp 82-98

Dorward EJ, and Barisas BG (1984) Acute toxicity screening of water pollutants using a bacterial electrode. Envion Sci Technol 18(12):967-972 
Dutka BJ and Kwan KK (1982) Application of four bacterial screening procedures to assess changes in the toxicity of chemicals in mixtures. Environ Pollut, ser A 29:125-134

Ekwall B (1983) Screening of toxic compounds in mammalian cell cultures. Ann NY Acad Sci 407:64-77

Jacobs EE, Jacob M, Sanadi Dr, and Bradley LB (1956) Uncoupling of oxidative phosphorylation by cadmium ion. J Biol Chem 223:147-156

Karube I, Nakahara T, Matsunaga T, and Suzuki S (1982) Salmonella electrode for screening mutagens. Anal Chem 54:1725-1727

Khan HM, Cutkomp LK (1982) Effects of DDT, DDE, and PCBs on mitochondrial respiration. Bull Environm Contam Toxicol 29:577-585

Kleiner D (1974) The effect of $\mathrm{Zn}^{2+}$ ions on mitochondrial electron transport. Arch Biochem Biophys 165:121-125

Kronenberg JJ, and Brabec MJ (1982) Invitro effects of 10,10'oxybisphenoxarsine on isolated rat liver. Toxicol Appl Pharmacol 62:282-287

Lehninger AL (1976) Biochemistry. Worth, New York pp 518-520

Masini A, Ceccarelli-Stanzani D, Muscatello U (1983) The effect of oligomycin on rat liver mitochondria respiring in state 4. FEBS Letters 160:137-140

Maugh TH (1979) Toxicology: New Laws Mean New Instruments. Science 203:1327-1328

National Institute for Occupational Safety and Health (1984) Registry of toxic effects of chemical substances. U.S. Department of Health and Human Services, Ohio

Ogata M, Mori T, Izushi F, Etoh K, Sakai R, Meguro T, Inoue B (1983) Classification of potentially toxic chemicals based on their effects on mitochondrial respiration. Physiol Chem Phys Med 15:229-232

Pisani DE, Elliott AJ, Hinman DR, Aaronson LM, Pardini RS (1986) Relationship between inhibition of mitochondrial respiration by naphthoquinones, their antitumor activity, and their redox potential. Biochem Pharmac 35:3791-3798

Tzagoloff A (1982) Mitochondria. In: Siekevitz P (ed) Cellular Organelles. Plenum, New York pp 131-156

United States Environmental Protection Agency (1979) Water related environmental fate of 129 priority pollutants. Vols A\&B, EPA-440.4-79-029, Washington

Received August 20, 1989; accepted November 20, 1989. 